\title{
"The role of knowledge management in institutional strategy development and competitiveness at leading African universities"
}

\begin{tabular}{|c|c|}
\hline AUTHORS & $\begin{array}{l}\text { Sachin Suknunan (D https://orcid.org/0000-0002-7296-8059 } \\
\text { Manoj Maharaj }\end{array}$ \\
\hline ARTICLE INFO & $\begin{array}{l}\text { Sachin Suknunan and Manoj Maharaj (2019). The role of knowledge } \\
\text { management in institutional strategy development and competitiveness at } \\
\text { leading African universities. Knowledge and Performance Management, 3(1), 19- } \\
\text { 30. doi:10.21511/kpm.03(1).2019.03 }\end{array}$ \\
\hline DOI & http://dx.doi.org/10.21511/kpm.03(1).2019.03 \\
\hline RELEASED ON & Monday, 22 July 2019 \\
\hline RECEIVED ON & Saturday, 01 June 2019 \\
\hline ACCEPTED ON & Monday, 01 July 2019 \\
\hline LICENSE & $\begin{array}{l}(c) \text { EY } \\
\text { This work is licensed under a Creative Commons Attribution } 4.0 \text { International } \\
\text { License }\end{array}$ \\
\hline JOURNAL & "Knowledge and Performance Management" \\
\hline ISSN PRINT & $2543-5507$ \\
\hline ISSN ONLINE & 2616-3829 \\
\hline PUBLISHER & LLC "Consulting Publishing Company "Business Perspectives" \\
\hline FOUNDER & o. z o.o. Kozmenko Science Publishing \\
\hline
\end{tabular}

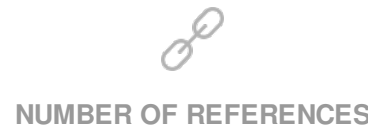

40
NUMBER OF FIGURES

5

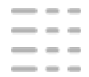

NUMBER OF TABLES

5

(C) The author(s) 2023. This publication is an open access article. 


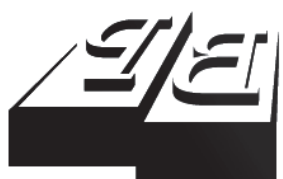

BUSINESS PERSPECTIVES

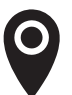

LLC "CPC "Business Perspectives" Hryhorii Skovoroda lane, 10, Sumy, 40022, Ukraine

www.businessperspectives.org

Received on: $1^{\text {st }}$ of June, 2019 Accepted on: $1^{\text {st }}$ of July, 2019

(c) Sachin Suknunan,

Manoj Maharaj, 2019

Sachin Suknunan, Doctor, Student Services Division, University of KwaZulu-Natal, South Africa.

Manoj Maharaj, Professor, School of Management, IT and Governance, University of KwaZulu-Natal, South Africa.

\section{(c) (i)}

This is an Open Access article, distributed under the terms of the Creative Commons Attribution 4.0 International license, which permits unrestricted re-use, distribution, and reproduction in any medium, provided the original work is properly cited.

\title{
THE ROLE OF KNOWLEDGE MANAGEMENT IN INSTITUTIONAL STRATEGY DEVELOPMENT AND COMPETITIVENESS AT LEADING AFRICAN UNIVERSITIES
}

\begin{abstract}
The role of knowledge management as a strategic intervention in higher education in developing economies has not been studied extensively. Higher education plays a central role in a country's economy through knowledge creation and dissemination to its stakeholders. The main purpose of this article was to examine the role and influence of knowledge management in decision-making and strategy formulation at leading universities in Africa and to establish if knowledge management was adding value and competitiveness to the institutions. A survey across 20 leading African universities was conducted in 2014. A mixed method of quantitative and qualitative approaches was adopted. The results show that knowledge management does have the potential to positively influence institutional strategy formulation, but should ideally be represented at executive level for its potential to be fully realized. More knowledge management practice is needed in the areas of academic teaching and learning, and research. There was a lack of sophisticated and powerful knowledge management Information Systems in most of Africa's leading institutions. Those institutions that utilized KM more strategically, inclusive of specialized KM Information Systems were the higher ranked institutions. This suggests that knowledge management could play a crucial role in a University's success and competitiveness.
\end{abstract}

\section{Keywords}

\section{JEL Classification I23, O43, O32}

\section{INTRODUCTION}

The changing nature of universities, driven by the knowledge society, requires that institutions embrace knowledge management (KM) so that they may effectively respond to the need for rapid innovation, driven by globalization spurred on by Information and Communication Technology (ICT). In light of this, it should be noted that as early as 2002, Oosterlinck and Leuven (2002) posited that universities have a major role to play in the modern economy as knowledge had surpassed wealth and labor and had become the dominant driver of economic value. The knowledge economy, driven by information and communication technologies, presents low barriers to entry to new smaller, more agile higher education service providers thus placing further pressure on traditional higher educational institutions to remain relevant. This means that massification, globalization and the changing economic environment are forcing higher education (HE) institutions to rethink their teaching, research and business methods (Cranfield \& Taylor, 2008). This suggests an increasingly important role for knowledge management. Numerous studies have affirmed that higher educational institutions can achieve high levels of produc- 
tivity, innovation, functionality, quality and competitiveness by using KM (Psarras, 2006; Metaxiotis \& Psarras, 2003; Kende, Noszkay, \& Seres, 2007; Cranfield \& Taylor, 2008; Krajcso, 2009; Laal, 2010; Lubega, Omona, \& Van der Weide, 2011).

\section{THE RESEARCH PROBLEM, PURPOSE AND OBJECTIVES}

Extant research illustrates the strategic role of KM. The supporting literature shows that an abundance of research exists on KM and its strategic role in higher education in both developed and developing countries. These studies show how KM is being seen and used as a fundamental and strategic entity in $\mathrm{HE}$ institutions and is yielding significant benefits such as increased levels of quality, innovation, decision making and productivity. However, there is a lack of evidence whether KM is being used in a similar way in African HE. A comprehensive literature search revealed a dearth of this type of research in an African context. Whether HE institutions in Africa are actually utilizing $\mathrm{KM}$ in a strategic way to enhance productivity, efficiency, innovation and competitiveness at their institutions is unknown. Knowledge management is an important resource for advancing the development of Africa into the 21st century (Mchombu, 2007). It is therefore important to ascertain if African HE institutions can attain similar levels of quality, innovation and productivity as compared to HE institutions in developed countries through the strategic use of KM. It is also important to establish if universities in Africa are employing KM as strategic information practices to develop institutional strategy that can drive institutional value.

This paper reports on research to establish whether knowledge management is being used at the leading higher educational institutions in Africa to inform strategy formulation.

\section{LITERATURE REVIEW}

\subsection{Knowledge management}

Knowledge management (KM) may be viewed as the effective creation, control, transfer and dissemination of knowledge that is derived from an organization's intellectual resources and that can be used to:

- generate new capabilities, promote innovation and performance, and improve customer value (Beckman, 1999);

- make strategic decisions and take strategic actions (Kidwell, Linde, \& Johnson, 2000);

- better achieve organizational goals (Marshall et al., 2003);

- promote competitive advantage and strategy development (Kebede, 2010);

- facilitate organizational learning (Kebede, 2010).

It is also important to understand that $\mathrm{KM}$ is not just about technology and systems that are used to generate knowledge but instead involves three crucial elements (people, processes and technology) to be complete and for its potential to be realized (Petrides \& Nodine, 2003). Building on the technology aspect of KM, Knowledge Management Information Systems (KMIS) arise. These are information systems that are designed purely for the intense analytical processing of information and data with the aim of generating key 'knowledge' reports from that data (Elbashir, Collier, \& Michael, 2008; Azma \& Mostafapour, 2012). There are a variety of KMISs. Some of the most widely used KMIS include data mining, data-warehouses, online analytical processing (OLAP), predictive analytics and digital dashboards. Kebede (2010) also argued that Knowledge Management Information Systems can fulfil key organizational purposes of gaining a sustainable competitive advantage, facilitating strategy development and improving organizational learning.

\subsection{Knowledge management and higher education}

Higher education plays a crucial role in a country's economy. Higher education is where key 
knowledge is generated through research, which is then disseminated to students who take this knowledge and apply it in practice (professional/ workforce) and/or further research. This in turn contributes to a country's economic and social development (Cranfield \& Taylor, 2008; Pircher \& Pausits, 2011). A university's key role in a knowledge driven economy suggests that KM should be a key driver of its institutional strategy. The fluid nature of the knowledge economy places pressure on universities to be agile as emerging players and competing markets for knowledge production emerge. Loh, Tang, Menkhoff, Chay, and Evers (2003) argued that KM plays a key role in assisting universities to address the demands of productivity and competitiveness. It has been shown that HE institutions can attain higher degrees of quality, innovation, functionality and competitiveness by using knowledge management (Psarras, 2006). Yang (2007) asserts that within the higher educational environment, knowledge management has become a substantial part of quality enhancement, leading to cooperative efforts to create and share knowledge. This then improves overall productivity of the institution. By implementing KM practices in higher education, the nature of the institution changes which, in turn, leads to better decision-making, reduced costs and enhanced quality of both academic and administrative services (Kidwell, Linde, \& Johnson, 2000; Laal, 2010).

Cranfield and Taylor (2008) showed that the effects of globalization and market forces had a direct influence on the institutions' ability to uphold their prestige and rank in the United Kingdom. Significantly, they showed that organizational culture played a vital role in the implementation and dissemination of $\mathrm{KM}$ at these institutions. Using the Salt Lake Community College (Utah) as a case study, Sahay and Mehta (2010) showed how KM information systems could strategically assist $\mathrm{HE}$ institutions in improving student success rates, by addressing the challenge of predicting the academic paths of students. Lubega, Omona, and Van der Weide (2011) took a strategic and theoretical approach to integrating $\mathrm{KM}$ technologies with higher education processes and demonstrated that KM improved overall organizational performance and competitiveness. Knowledge management processes provided tangible rewards for key HE stakeholders as it harnessed a large range of enabling technologies and tools. These tools and technologies integrated with KM showed a significant improvement in overall institutional performance in terms of decision-making, teaching and learning, process enhancement and more (Lubega, Omona, \& Van der Weide, 2011).

While numerous studies reveal that knowledge management is critical to the development and maintenance of quality education in developed countries, this is also true in developing countries, as shown by Ghaffari, Rafeie, and Ashtiani (2012) in an Iranian Higher Education context, where they emphasized the role of knowledge management in strategy development. In addition, the use of KM in problem solving and strategic decision making towards improved organizational performance was highlighted by Shams, Rad and Hooshmand (2009) in a Tehran HE context. Their study was based on two dimensions, the first of which being the role of KM practices in problem-solving process and the second being the type of problem they addressed. The literature reveals that KM does play a strategic role in higher education and has a strong influence on institutional strategy. This in turn boosts institutional productivity, performance, quality and competitiveness. Furthermore, KM have also been shown to improve academic processes, operations and services at the institutions, which positively affects factors such as graduation rates. In this research, the role of $\mathrm{KM}$ as a driver of African higher educational institutional strategy formulation is investigated.

\section{RESEARCH METHODOLOGY}

\subsection{Respondents}

The population for this study comprised the top 10 ranked universities from South Africa together with the 10 highest ranked universities from Africa, outside of South Africa. This strategy prevented the vast majority of universities from being selected from South Africa. The rankings were obtained from two academic ranking websites for South Africa and greater Africa. The academic ranking for greater Africa were obtained from the academic ranking website, 'Africa.com - Top 10 universities in Africa' (Top 10 Universities in Greater Africa, 2013) and the academic ranking 
for South Africa came from 'Africa.com - Top 10 universities in South Africa' (Top 10 Universities in South Africa, 2013). This was further correlated with other ranking websites, such as 'Top 100 universities in Africa 2013' (Top 100 Universities in Africa, 2013) and Times Higher Education (2013a, 2013b) ranking for added reliability and validity. Fifteen universities participated in this research.

Table 1. List of universities in South Africa and greater Africa chosen for the study

\begin{tabular}{|c|c|}
\hline \multicolumn{2}{|r|}{$\begin{array}{l}\text { Source: Top } 10 \text { universities in Africa (2013) } \\
\text { Top } 10 \text { universities in South Africa (2013) }\end{array}$} \\
\hline $\begin{array}{c}\text { The universities } \\
\text { from South Africa (based } \\
\text { on academic ranking) }\end{array}$ & $\begin{array}{c}\text { The universities } \\
\text { from greater Africa (based } \\
\text { on academic ranking) }\end{array}$ \\
\hline University of Cape Town & Cairo University (Egypt) \\
\hline University of Stellenbosch & $\begin{array}{l}\text { The American University in Cairo } \\
\text { (Egypt) }\end{array}$ \\
\hline University of Pretoria & Makerere University (Uganda) \\
\hline $\begin{array}{l}\text { University of the } \\
\text { Witwatersrand }\end{array}$ & University of Nairobi (Kenya) \\
\hline University of KwaZulu-Natal & $\begin{array}{l}\text { University of Dar es Salaam } \\
\text { (Tanzania) }\end{array}$ \\
\hline University of South Africa & $\begin{array}{l}\text { University of Botswana } \\
\text { (Botswana) }\end{array}$ \\
\hline $\begin{array}{l}\text { University of the Western } \\
\text { Cape }\end{array}$ & University of Ghana (Ghana) \\
\hline Rhodes University & University of Lagos (Nigeria) \\
\hline University of Johannesburg & $\begin{array}{l}\text { Polytechnic of Namibia } \\
\text { (Namibia) }\end{array}$ \\
\hline $\begin{array}{c}\text { Cape Peninsula University of } \\
\text { Technology }\end{array}$ & $\begin{array}{l}\text { Addis Ababa University } \\
\text { (Tanzania) }\end{array}$ \\
\hline
\end{tabular}

Information Technology and Chief Information directorates from the selected universities were targeted as respondents. This allowed knowledge management to be viewed from both a technical perspective, which focused on the actual Knowledge Management Information Systems and from a strategic perspective, which focused on how knowledge derived from KMIS is being used to develop strategy.

\subsection{Data collection}

Both qualitative and quantitative data was collected for this research. A questionnaire was emailed to all respondents. Interviews with key personnel were conducted to support and enhance the quality of the results obtained from the questionnaire. This also added more depth to the data that was being collected as the interviews focused on underlying issues related to $\mathrm{KM}$.

\subsection{Analysis of results}

The quantitative data was analyzed using SPSS 21 , whilst the qualitative data was analyzed using Nvivo.

Quantitative analysis, shown in the paper, included frequency and correlation analysis. An overall Cronbach's Alpha reliability score of 0.7 was obtained. For the qualitative analysis, thematic analysis was done through the use of word clouds, cluster analysis and tree mapping. This resulted in the formulation of key themes and subthemes relating to KM.

\section{FINDINGS AND DISCUSSION}

\subsection{Reporting structure}

The level at which the KM manager reports at is an indicator of the value that the institution places on these structures. Twenty per cent of the respondents reported directly to the Vice Chancellor. One respondent reported to the Chancellor. The majority of the respondents reported to Deputy Vice Chancellors (DVCs) in various divisions. This included,

- DVC (Research);

- DVC (Teaching and Learning);

- DVC (Knowledge and Information Management);

- DVC (Finance and Administration);

- DVC (Administration).

This indicates that knowledge management in itself is not at the Executive level at the institutions. It is important to note that some of these executive members are experts in different disciplines and not Knowledge Management. This could mean that the true potential and strategic value of KM may not necessarily be realized by these executive members, especially when it comes to presenting $\mathrm{KM}$ at the Executive level. Only one institu- 
tion had a DVC of Knowledge and Information Management.

\subsection{Scanning of the higher education environment and collection of relevant data}

Only twenty per cent of the respondents scanned the Higher Education environment on a daily basis, $13.3 \%$ on a weekly basis and $13.3 \%$ on a monthly basis to collect information for strategic use. This entailed collecting information for:

- improving research and pedagogical practices;

- improving technological practices/operational processes;

- redefining institutional strategy;

- monitoring and keeping abreast of other university's standards and practices.

One leading institution did not scan the HE environment at all for collecting strategic information.

Figure 1 is a summary of the scoring patterns for the variables that constituted how data/information that was collected was being used by the respondents' division/department.

Even though majority of the institutions agreed that data/information that was collected (through scanning of environment) was used towards the above-listed purposes, very few of these leading institutions 'strongly agreed'. Thus respondents may not be entirely certain if data/information that is being collected/gathered through scanning of the HE environment is actually being used strategically.

There was also a positive correlation $(0.530, \mathrm{p}<$ 0.05 ) between how often the department/division scanned the HE environment to collect data and the use of that data for student enrollment and performance analysis. The Global Higher Education environment is continuously changing and if African universities are to remain competitive on a global scale, it is imperative that they scan the HE environment regularly and collect the most updated information, which can lead to improved decision-making regarding current processes, operations and strategies. This is supported by the findings of Jiménez-Jiménez and CegarraNavarro (2006).

\subsection{Knowledge management}

All of the respondents agreed that KM does add value to their divisions/departments.

Table 2. Does KM add value to the division/ department?

\begin{tabular}{l|c}
\hline & Valid percent \\
\hline Strongly agree & 73.3 \\
\hdashline Agree & 26.7 \\
\hline Total & 100.0 \\
\hline
\end{tabular}

Figure 2 represents the regularity of KM presentations to university authorities. More than a

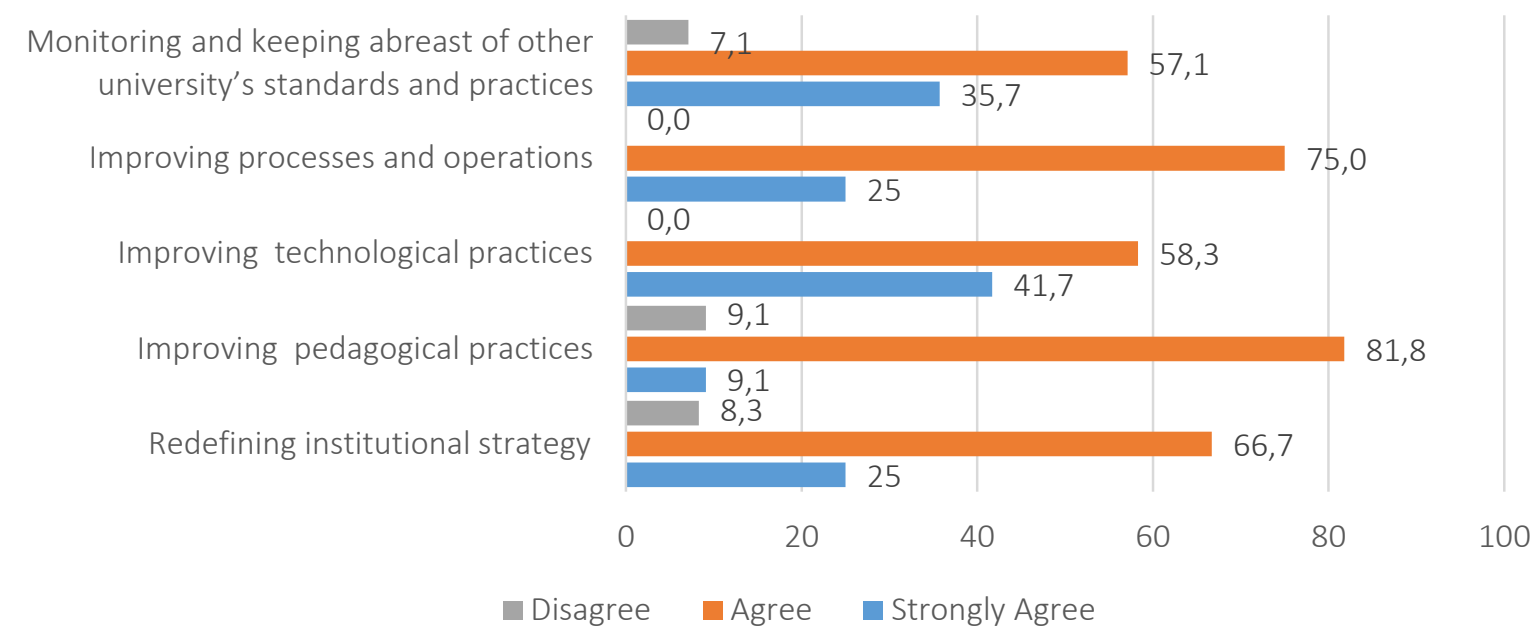

Figure 1. How collected data/information is being used by the respondents' division/department 


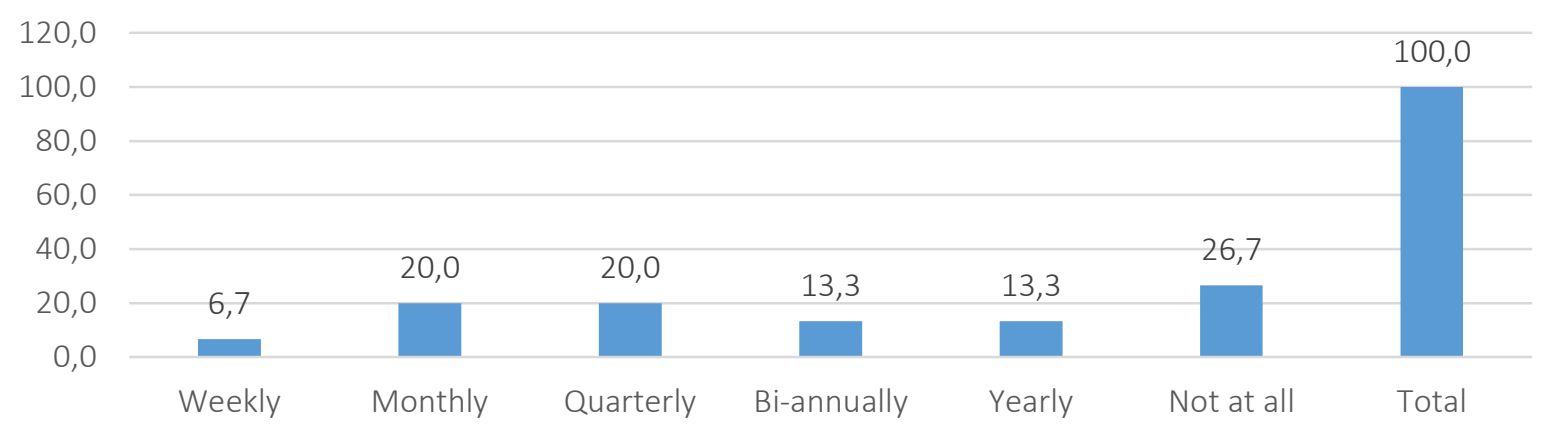

Figure 2. Frequency of institutional knowledge management presentations

quarter of the respondents (26.7\%) from these 15 leading universities did not make any institutional KM presentations to the university authorities. Of those that did, reports were presented most often either monthly $(20.0 \%)$ or quarterly $(20.0 \%)$, while only one of the universities presented on a weekly basis. Thus, $73.3 \%$ of leading universities were not making institutional KM presentations regularly, if at all.

It was also shown that there is a positive correlation between the frequency of institutional KM presentations and the provision of reliable knowledge reporting to executive management $(0.675, \mathrm{p}<0.01)$. knowledge management needs to be made more visible institution wide (Laal, 2010; Omona, Van der Weide \& Lubega, 2010) so that its value can be realized at the university executive level thus facilitating better decision-making. This can be done through more KM presentations across the institution (institution-wide). Hence the argument raised is that the more institutional-wide KM presentations are made, the more likely the executive management and authorities of the institution will acknowledge the potential of KM. This in turn will lead to executive management drawing on knowledge derived from KM reports to inform decisions at executive level. Decisions taken at Executive level are often decisions that pertain to institutional strategy. This then places KM as the driver of improved decision-making and institutional strategy development that can enhance an organization in terms of performance, productivity and overall institutional strategy (Metaxiotis \& Psarras, 2003; Chen, Huang \& Cheng, 2009; Laal, 2010; Lubega, Omona \& Van der Weide, 2011; Pircher \& Pausits, 2011).

An indication of how KM was being used in a strategic context is shown in Figure 3. Respondents were asked to select the categories where KM was mostly used at their institutions. The scores marked with an asterisk ${ }^{*}$ ) reflected areas in the 15 leading African universities where KM was not being used effectively. These were key areas in a university setting and yet showed minimal knowledge management practices. Furthermore, the overall average of all scores reflected $52 \%$ of strategic use of KM across the sample. This does not reflect a strong and strategic use but leans more towards a mediocre KM practice.

Table 3 shows that the most frequently used KMIS, marked with an asterisk $\left(^{\star}\right)$, were Organizational databases $(86.7 \%)$ and Data warehouses (58.3\%). Digital Dashboards, Online Analytical Programming (OLAP), Predictive Systems and Institutional Intelligence systems seem to be very infrequently used. These types of KMIS were highly prevalent in developed countries (Delavari, Phon-Amnuaisuk \& Beikzadeh, 2008; Sahay \& Mehta, 2010; Sharman, 2010; Goyal \& Vohra, 2012; King, 2013). Leading universities in Africa seem to be deficient in these types of systems.

Figure 4 indicates what the knowledge gathered from the various KMIS (Table 4) are being used for.

There was complete agreement with all of the statements with majority leaning on 'Strongly agree'. However, when it came to using knowledge gathered from KMIS to 'monitor and improve academic and research methods, standards and output', there was a mixed reaction. There was a $28.6 \%$ level of disagreement and a 'don't know' of $7.1 \%$. In addition, only $28.6 \%$ strongly agreed. This further indicates that leading African universities are not using KM systems to enhance their core functions. 


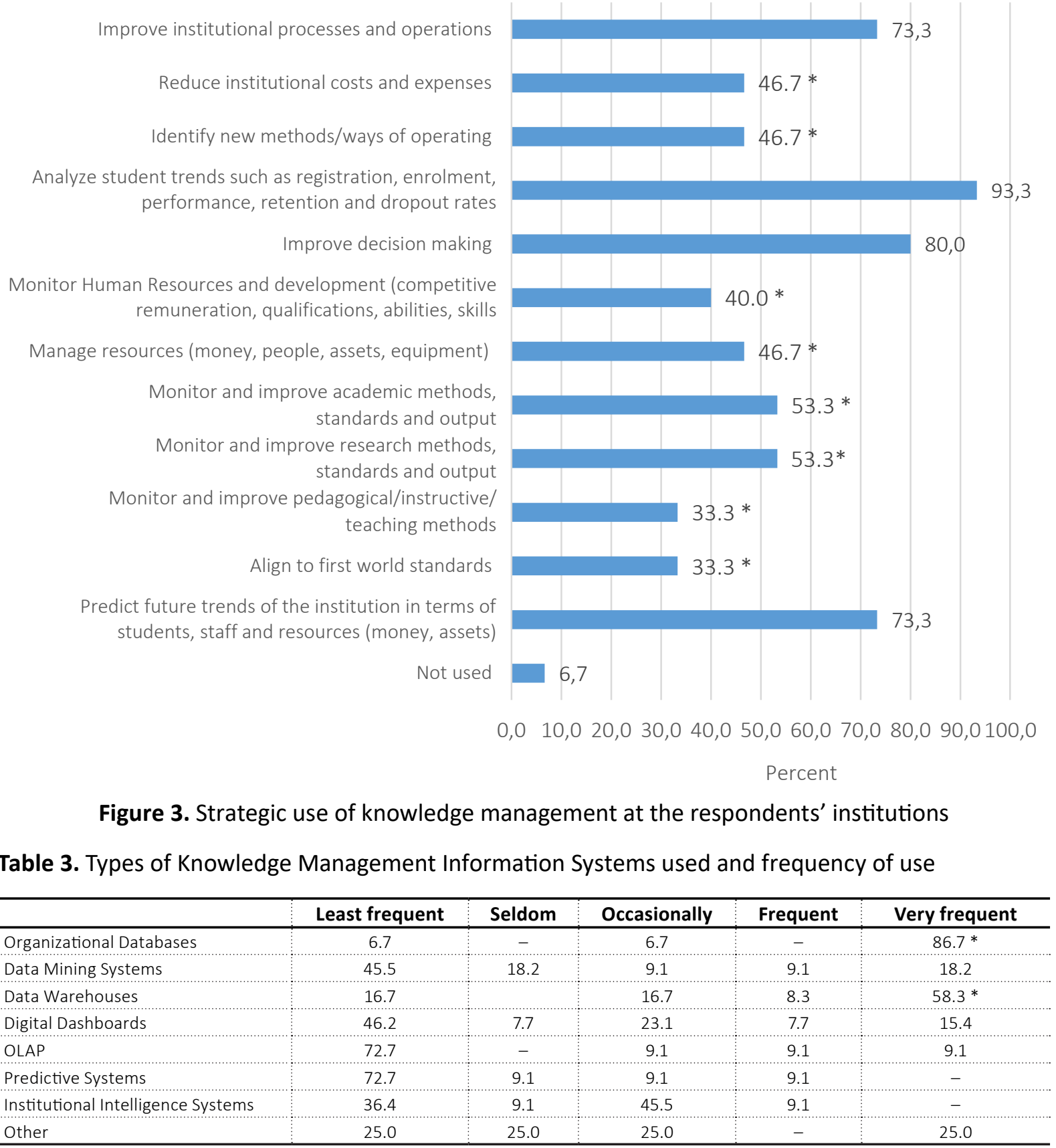

Figure 5 shows that unlike universities in developed countries, African universities do not use KMIS as a strategic facilitator and technology enabler of research.

Table 5 shows that, overall, respondents are of the opinion that KM practice (including KMIS) has been beneficial to their institutions.

There was overall high levels of agreement that KM practice (including KMIS) has led to the institutions becoming more competitive and had promoted continuous learning at their institutions.
However, most respondents do not seem to be strongly convinced in this belief. This is due to the following:

- only $13.3 \%$ strongly agreed that KM practice (including KMIS) had improved overall efficiency, while $6.7 \%$ disagreed. Further $6.7 \%$ did not know;

- only $6.7 \%$ strongly agreed KM practice (including KMIS) had enhanced academic research activity and a substantial $26.7 \%$ did not know; 


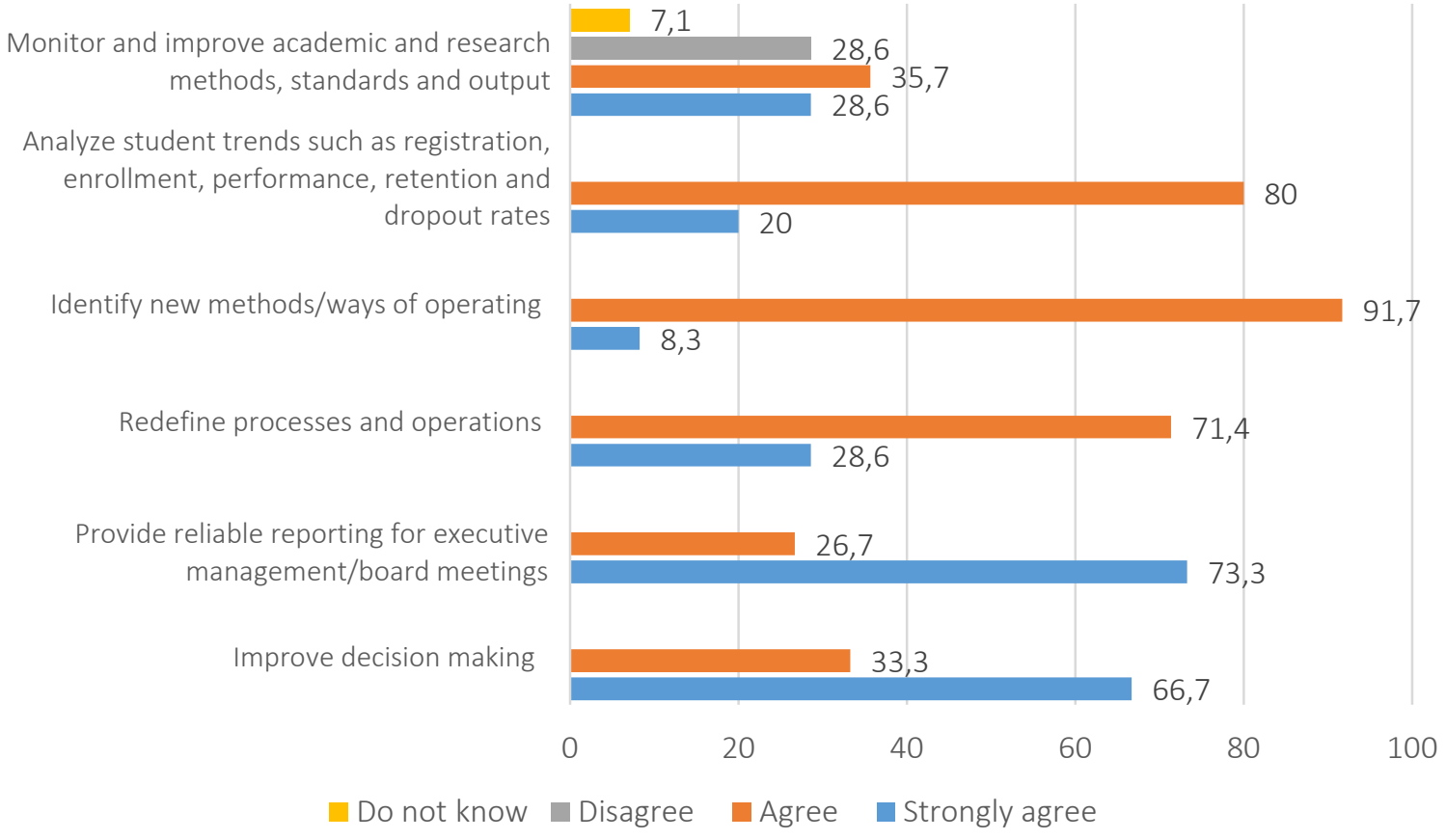

Figure 4. Strategic use of knowledge management

Table 4. Knowledge management practice and KMIS improves efficiency, competitiveness and continuous learning

\begin{tabular}{l|c|c|c|c}
\hline & $\begin{array}{c}\text { Strongly } \\
\text { agree }\end{array}$ & Agree & $\begin{array}{c}\text { Do not } \\
\text { know }\end{array}$ & Disagree \\
\hline Improved overall efficiency & 13.3 & 73.3 & 6.7 & 6.7 \\
\hline Enhanced academic research activity & 6.7 & 66.7 & 26.7 & \\
\hline Led to your institution becoming more competitive & 13.3 & 80.0 & - & 6.7 \\
Provided a means of continuous learning & 6.7 & 73.3 & 13.3 & 6.7 \\
\hline
\end{tabular}

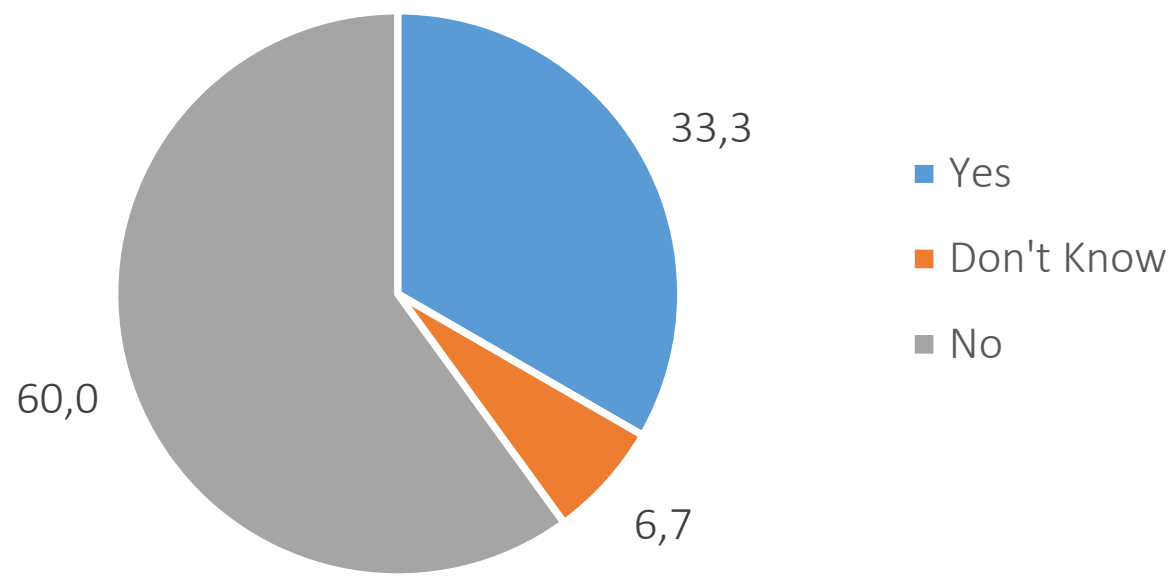

Figure 5. Provision of Knowledge Management Systems to facilitate academic research 
- there was an overall 93.3\% agreement, however, only $13.3 \%$ strongly agreed that KM practice (including KMIS) had made their institution more competitive, while $6.7 \%$ disagreed.

Results revealed a strong positive correlation between the importance given to KMIS and the use of these systems to improve academic and research methods, standards and outputs $(0.694, \mathrm{p}<0.01)$. Studies by Loh et al. (2003), Chandarasupsang, Harnpornchai, Chakpitak, and Dahal (2006), Delavari, Phon-Amnuaisuk, and Beikzadeh (2008), Sahay and Mehta (2010) and Ghaffari, Rafeie, and Ashtiani (2012) found that when KM Information Systems are integrated into academia and research, it leads to significant benefits such as an improvement in quality, productivity, efficiency, interactivity, collaboration and flexibility. This inevitably lead to holistic enhancement of academic and research standards and outputs. Academic and research standards and outputs are the most critical aspects of any university, which in turn leads to the generation and dissemination of knowledge (Oosterlinck \& Leuven, 2002; Metaxiotis \& Psarras, 2003).

In addition, there is a strong correlation between the use of KM to identify new methods/ways of operating and the use of KMIS to promote continuous learning at the institutions $(0.631, \mathrm{p}<0.05)$. This allows the institutions to 'learn' to identify new and innovative ways of their improving through $\mathrm{KM}$. This is also supported by findings of Tippins and Sohi (2003), Garcia-Morales, Llorens-Montes, and Verdu-Jover (2007), Phang, Kankanhalli, and Ang (2008), and Hung, Lien, Yang, Wud, and Kuo (2011) who found that organization learning through KM fostered innovation and newer methods of processes and operations. Lastly, it is shown that the provision of KMIS to facilitate academic research is correlated to the improvement of academic research activity $(0.555, \mathrm{p}<0.05)$, which is supported by Loh et al. (2003), Metaxiotis and Psarras (2003) and Chandarasupsang et al. (2006) and Mamta (2012).

\subsection{Findings from qualitative research}

The qualitative arm of the study took the form of open ended interviews to enhance the quality of the results obtained from the questionnaire (quantitative). The interviews were done via telephone and skype and data from the interviews was recorded, transcribed and analyzed qualitatively.

These interviewed universities are listed in the form of numbers and location.

Table 5. University respondents by number and location

\begin{tabular}{l|c}
\hline University 1 & South Africa \\
\hline University 2 & North Africa \\
\hline University 3 & South Africa \\
\hline University 4 & South Africa \\
\hline University 5 & North Africa \\
\hline University 6 & North Africa \\
\hline University 7 & South Africa \\
\hline University 8 & North Africa \\
\hline University 9 & South Africa \\
\hline University 10 & North Africa \\
\hline University 11 & South Africa \\
\hline
\end{tabular}

Note: University 1 is regarded as the most leading university in Africa. University 2 is regarded as the most leading in North Africa. University 3 is regarded as the second most leading in South Africa and Africa. University 9 is the largest distance-learning university in Africa.

The aspect of 'influence' was a key theme generated from the qualitative data. Five of the leading African institutions agreed that $\mathrm{KM}$ had a positive influence of institutional strategy. This can be broken down into $\mathrm{KM}$ being a positive influence because it:

- $\quad$ adds value (University 3);

- drives policy development (University 9);

- enhances performance (University 9);

- promotes transformational strategy in relation to centralized access to knowledge resources (University 1);

- $\quad$ drives strategic plans (University 6);

- brings about positive outcomes (University 5).

Another relevant theme generated was the 'Motivation for the use of Knowledge Management'. The motivation factors included:

- strategy development, implementation, and evaluation (Universities 1, 2, 3, 4, 59 and 11); 
- achieving targets and meeting goals (Universities 1, 3, 7 and 11);

- $\quad$ supporting university processes (Universities 1 and 3);

- improving service (Universities 1, 3, 6 and 7);

- informed and improved decision-making (Universities 1, 4, 5, 8 and 9);

- international benchmarking (Universities 1, 3, 4 and 9);

- increasing competitiveness (Universities 1,2, $3,4,5,6$ and 10);

- increasing transparency and accountability (Universities 3, 6 and 9);

- monitoring and evaluation (University 1);

- reducing institutional costs ((Universities 1,4 , 5 and 9);

- understanding institutional trends (Universities 1, 4 and 9);

- improvement academic standards and research strategies (Universities 1 and 3).

Holistically, all of the above processes constitute 'institutional strategy development'. In aggregate, as one may see, $\mathrm{KM}$ is being used towards strategy development by many of these leading universities in Africa. This is hence a conclusive finding that $\mathrm{KM}$ can be seen as an effective enabler of strategy development, implementation and evaluation. It is noteworthy that Universities 1, 3 and 9 seem to be making the most strategic use of KM to inform strategy development, and these two universities are often regarded as top 2 academic leaders in Higher Education in Africa whilst University 9 being the largest. In addition, Universities 1 and 3 seem to be the only universities that utilize KM in Academic and Research Strategies. This seems to be raising their international Academic and Research profile. Furthermore, the qualitative results show that there is a lack of specialized and sophisticated KMIS used in the leading African HE institutions. These systems include digital dashboards, performance scorecards, data-mining, OLAP and predictive systems, which are mainly used at HE institutions in developed countries. These types of systems were used by only a few of the leading universities in Africa.

- dashboards (Universities 1, 3, 9);

- $\quad$ scorecards (University 9);

- predictive analytics (Universities 1, 2, 3, 7, 9).

This correlates with the argument mentioned above about Universities 1 and 3 being academic leaders in African Higher Education and 9 being leaders in size.

Holistically, the results indicate knowledge management does influence institutional strategy and plays an important role in providing knowledge on demand for strategic decision-making and strategy formulation. Those institutions that utilize KM more strategically in relation to strategy formulation as well as utilize more specialized KMIS seem to be the higher ranked institutions suggesting that KM may play a crucial role in a University's success.

\section{CONCLUSION}

This research explored the role of knowledge management in African higher educational institutions as a means of informing strategy development through better decision-making. The research found that Knowledge management does have the potential to positively influence institutional strategy formulation. It has been shown that knowledge management is primarily used in strategy formulation at operational and support areas of the institutions as opposed to academia and research. There was also a lack of sophisticated and powerful Knowledge Management Information Systems in most of Africa's leading institutions. Additionally, knowledge management portfolios were not formally represented at the highest executive level of the institution, where it ideally should be. While the leading Universities in Africa 
are key players in the knowledge environment, these higher educational institutions themselves should become learning organizations facilitated by strong knowledge management practices. Results indicate that those institutions that utilized knowledge management more strategically inclusive of specialized Knowledge Management Information Systems were the higher ranked institutions. This suggests that knowledge management could play a crucial role in a University's success and competiveness.

\section{REFERENCES}

1. Azma, F., \& Mostafapour, M. A. (2012). Business intelligence as a key strategy for development organizations. Procedia Technology, 1, 102-106. http://doi. org/10.1016/j.protcy.2012.02.020

2. Beckman, T. J. (1999). The current state of knowledge management. In J. Liebowitz (Ed.), Knowledge Management Handbook (pp. 1122). New York: CRC Press LLC.

3. Chandarasupsang, $\mathrm{T}$., Harnpornchai, N., Chakpitak, N., \& Dahal, K. (2006). Enhancing University Research Activities with Knowledge Management, The International conference on Software Knowledge Information Management and Applications (SKIMA). At International Conference on Software Knowledge Information Management and Applications (SKIMA 2006) Chiang Mai, Thailand. Bradford: University of Bradford, School of Informatics. Retrieved from http:// hdl.handle.net/10454/2470

4. Chen, M., Huang, M., \& Cheng, Y. (2009). Measuring knowledge management performance using a competitive perspective: An empirical study. Expert Systems with Applications, 36(4), 84498459. http://doi.org/10.1016/j. eswa.2008.10.067

5. Cranfield, D. J., \& Taylor, J. (2008). Knowledge Management and Higher Education: A UK case Study. The Electronic Journal of Knowledge Management, 6(2), 85-100.

6. Delavari, N., Phon-Amnuaisuk, S., \& Beikzadeh, M. R. (2008). Data Mining Application in Higher Learning. Informatics in Education Institutions, 7(1), 31-54.

7. Elbashir, M. Z., Collier, P. A., \& Michael, D. J. (2008). Measuring the effects of business intelligence systems: The relationship between business process and organizational performance. International Journal of Accounting Information Systems, 9, 135-153.

8. Garcia-Morales, V. J., LlorensMontes, F. J., \& Verdu-Jover, A. J. (2007). Influence of personal mastery on organizational performance through organizational learning and innovation in large firms and SMEs. Technovation, 27(9), 547568. http://doi.org/10.1016/j. technovation.2007.02.013

9. Ghaffari, H., Rafeie, M., \& Ashtiani, A. C. (2012). Quality Open Higher Education via Knowledge Management. Journal of Basic and Applied Scientific Research, 2(2), 1787-1792. Retrieved from https://www.textroad.com/pdf/JBASR/J.\%20Basic.\%20Appl.\%20Sci.\%20Res.,\%20 2(2)1787-1792,\%202012.pdf

10. Goyal, M., \& Vohra, R. (2012). Applications of Data Mining in Higher Education. International Journal of Computer Science Issues, 9(2-1), 113-120. Retrieved from https://pdfs.semanticscholar.org/0 fc7/05ef34776db8f50d64b4b82bbd 11ca5ebee5.pdf

11. Hung, R. Y. Y., Lien, B. Y., Yang, B., Wud, C. M., \& Kuo, Y. M. (2011). Impact of TQM and organizational learning on innovation performance in the high-tech industry. International Business Review, 20(2), 213-225. http://doi.org/10.1016/j.ibusrev.2010.07.001

12. Jiménez-Jiménez, D., \& Cegarra-Navarro, J. G. (2006). The performance effect of organizational learning and market orientation. Industrial Marketing Management, 36(6),
694-708. https://doi.org/10.1016/j. indmarman.2006.02.008

13. Kebede, G. (2010). Knowledge management: An information science perspective. International Journal of Information Management, 30(5), 416-424.

14. Kende, G., Noszkay, E., \& Seres, G. (2007). Role of the knowledge management in modern higher education - the e-learning. Education, 6(4), 559-573. Retrieved from http://drseres. com/publik/pdf/aarms_2007.pdf

15. Kidwell, J. J., Linde, K. V., \& Johnson, S. L. (2000). Applying corporate Knowledge Management practices in higher education. EDUCAUSE QUARTERLY, 4, 28-33. Retrieved from https://er.educause.edu/ / media/files/articles/2000/12/ eqm0044.pdf?la=en

16. King, A. (2013). Higher Education Turns to Predictive Analytics. Retrieved from http://the-modeling-agency.com/higher-educationturns-predictive-analytics/

17. Krajcso, Z. (2009). Idea Exchange in Translation Studies. Proceedings of International Conference on Education and New Learning Technologies EDULEARN09 (pp. 2989-2995). Barcelona, Spain.

18. Laal, M. (2010). Knowledge management in higher education. Procedia Computer Science, 3, 544-549. https://doi.org/10.1016/j. procs. 2010.12 .090

19. Loh, B., Tang, A., Menkhoff, T., Chay, Y., \& Evers, H. D. (2003). Applying Knowledge Management in University Research (Paper No. 1918). Research Collection Lee Kong Chian School of Business. Retrieved from https://ink.library. smu.edu.sg/lkcsb_research/1918/ 
20. Lubega, T. J., Omona, W., \& Van der Weide, T. (2011). Knowledge Management Technologies and Higher Education Processes: Approach to Integration for Performance Improvement. International Journal of Computing and ICT Research, 5(Special Issue), 55-68. Retrieved from http://ijcir. mak.ac.ug/specialissue2011/article7.pdf

21. Mamta, B. (2012). Institutional Knowledge to Institutional Intelligence: A Data Mining Enabled Knowledge Management Approach. International Journal of Computational Engineering Research, 2(5), 1356-1360. Retrieved from https://pdfs.semanticscholar.org/0c0c/9690c0cec c4e1f0519e702ccf73fb92ec81f.pdf

22. Marshall, B., Zhang, Y., Chen, H., Lally, A., Shen, R., Fox, E., \& Cassel, L. N. (2003). Convergence of Knowledge Management and E-Learning: the GetSmart Experience. Proceedings of the 2003 Joint Conference on Digital Libraries (JCDL'03) (pp. 135-146). Houston. https://doi.org/10.1109/ JCDL.2003.1204854

23. Mchombu, K. J. (2007). Harnessing knowledge management for Africa's transition to the 21 st century. Information Development, 23(1), 25-42. https://doi. org/10.1177/0266666907075628

24. Metaxiotis, K., \& Psarras, J. (2003). Applying Knowledge Management in Higher Education: The Creation of a Learning Organisation. Journal of Information and Knowledge Management, 2(4), 353-359.

25. Omona, W., Van der Weide, T., \& Lubega, J. (2010). Using ICT to enhance Knowledge Management in higher education: A conceptual framework and research agenda. International Journal of Education and Development using Information and Communication Technology (IJEDICT), 6(4), 83-101. Retrieved from https://www.researchgate. net/publication/235342037_Using_ICT_to_enhance_Knowledge_Management_in_higher_.
education_A_conceptual_framework_and_research_agenda

26. Oosterlinck, A., \& Leuven, K. U. (2002). Knowledge management in post-secondary education: Universities. Retrieved from http:// www.oecd.org/innovation/research/2074921.pdf

27. Petrides, L., \& Nodine, T. (2003). Knowledge Management in Education: Defining the Landscape. California: Institute for the Study of Knowledge Management in Education. Retrieved from https://www.iskme.org/ file? $\mathrm{n}=$ Knowledge-Managementin-Education-Defining-the-Landscape\&id $=932$

28. Phang, C. W., Kankanhalli, A., \& Ang, C. (2008). Investigating organizational learning in eGovernment projects: A multitheoretic approach. Journal of Strategic Information Systems, 17(2), 99-123. https://doi. org/10.1016/j.jsis.2007.12.006

29. Pircher, R., \& Pausits, A. (2011). Information and Knowledge Management at Higher Education Institutions. Management Information Systems, 6(2), 8-16. Retrieved from http://www.ef.uns. ac.rs/mis/archive-pdf/2011\%20 -\%20No2/02_Pircher,\%20Pausits. pdf

30. Psarras, J. (2006). Analysing the value of knowledge management leading to innovation. International Journal of Knowledge Management Studies, 1(1-2), 79-89.

31. Sahay, A., \& Mehta, K. (2010). Assisting Higher Education in Assessing, Predicting, and Managing Issues Related to Student Success: A Web-based Software using Data Mining and Quality Function Deployment. Academic and Business Research Institute Conference, Las Vegas. Retrieved from http://www.aabri.com/ LV2010Manuscripts/LV10127.pdf

32. Shams, G., Rad, A. M., \& Hooshmand, A. (2009). Knowledge Management Practices in Higher Education Institutes: A Different Approach. Proceedings of International Conference on Education and New Learning
Technologies EDULEARN09.

Barcelona, Spain

33. Sharman, D. (2010). An Introduction to Business Intelligence for Higher Education. Collegiate Project Services. Retrieved from https://www.scribd.com/document/137682713/An-Introduction-to-Business-Intelligence

34. Times Higher Education. (2013a). World University Rankings 2012-2013 methodology. Retrieved from https://www.timeshighereducation.com/world-universityrankings-2012-13-methodology

35. Times Higher Education. (2013b). World University Rankings 2012-2013. Retrieved from www. timeshighereducation.com/worlduniversity-rankings/2012-13/ world-ranking

36. Tippins, M. J., \& Sohi, R. S. (2003). IT competency and firm performance: Is organizational learning a missing link? Strategic Management Journal, 24(8), 745-761. https://doi.org/10.1002/ smj.337

37. Top 10 Universities in Greater Africa. (2013). Retrieved from http://www.africa.com/blog/thetop-10-universities-in-africa-parti (accessed on January 15, 2013)

38. Top 10 Universities in South Africa. (2013). Retrieved from http://www.africa.com/blog/top10-universities-in-south-africa/ (accessed on January 15, 2013)

39. Top 100 Universities in Africa. (2013). Retrieved from http:// www.studyabroaduniversities.com/UniversityList. aspx?Query=Top-100-Universities-in-Africa\&QueryId=127 (accessed on January 15, 2013)

40. Yang, J. T. (2007). Knowledge sharing: Investigating appropriate leadership roles and collaborative culture. Tourism Management, 28(2), 530-543. https://doi.org/10.1016/j.tourman.2006.08.006 